\title{
Italian Non-Fiction Literature Towards the Phenomenon of Contemporary Emigration From Africa and the Near East on the Apennine Peninsula*
}

\author{
Sylwia Szarejko \\ University of Bialystok, Bialystok, Poland
}

\begin{abstract}
The phenomenon of recent emigration on the Apennine Peninsula is quite fresh but intense. The emigration literary culture which is formed in this exile is not very abundant, but with distinct trends between certificating and documenting the experiences of immigrants. Reportages play an important role, including A Sud di Lampedusa. Cinque anni di viaggi sulle rotte dei migranti by Stefano Liberti, A Lampedusa. Affari, malaffari, rivolta e sconfitta dell'isola che voleva diventare la porta d'Europa, a book written by Italian journalists Fabio Sanfilippo and Alice Scialoja, and a diary La scelta di Catia written by Catia Pellegrino. In addition, many materials (including journalistic materials) confirm the existence of a preliminary reconnaissance, however, requires further research. Italian documentaries, personal opinions and comments that go far beyond literature in the strict sense complement the panorama of contemporary emigration which comes from Africa and the Near East. However, they allow us to understand better the area of psychosocial determinants of individual migration decisions and specificity of the migrants' experience, including the experience of the community. How do human solidarity and effectiveness work in the process of the emigration on the European continent? An analysis of the phenomenon of the emigration on the Apennine Peninsula is inextricably linked with the questions about the confrontation and integration, about the literature which is created in this community and the impact political correctness has on its shape, as well as about the new model of immigrant/the African/the European.
\end{abstract}

Keywords: Italian non-fiction literature, emigration, the Apennine Peninsula

\section{Introduction}

The phenomenon of recent emigration to the Apennine Peninsula is quite new but intense, and the emigration literary culture developing in this exile is not very abundant, but already manifests distinct trends of reporting and documenting the experiences of immigrants.

How do human solidarity and effectiveness work in the process of emigration to the European continent? The analysis of the phenomenon of emigration to the Apennine Peninsula is inextricably linked with questions about the confrontation and integration, about the literature which is created in this community and the impact political correctness has on its form, as well as about the new model of an immigrant/an African/a European.

\footnotetext{
*Acknowledgements: I would like to thank Anna Stawikowska for the linguistic correction. Sylwia Szarejko, Ph.D. student, Master, University of Bialystok.
} 


\section{The Italian Non-Fiction Literature}

In the Apennine Peninsula, the number of publications on the subject of migration is considerable, which confirms the fact that this phenomenon is worth scientific analysis. Therefore, undoubtedly, the FIERI project originated in Italy must also be presented. Thanks to the involvement of researchers from major research centers, the Forum Internazionale ed Europeo di Ricerche sull'Immigrazione (International and European Research Forum on Immigration ${ }^{1}$ ) has been established, which is engaged in research related to immigration and the integration of immigrant communities. Italian scientists would like to create a bridge between research on the one hand, and political discourse and social media on the other. According to scientists, comparative study will help to understand better the analyzed phenomenon.

In addition, FIERI organizes research projects, conferences, and publishes articles. Research conducted by the associated members cover a wide range of issues related to migration processes, with topics including integration, international cooperation, African emigration, as well as issues closely related to the case of emigration to Europe via the Mediterranean $\mathrm{Sea}^{2}$.

In 2008, there was the Italian premiere of a book by a writer, journalist and director, Stefano Liberti: A sud di Lampedusa. Cinque anni di viaggi sulle rotte dei migranti $(2013)^{3}$. The migrants interviewed by the journalist talked about preparing the journey to Europe and the related costs. The media have often reported the events of masses of Africans crossing sea, organized by crime groups, which is confirmed by numerous press articles $^{4}$. Liberti's protagonists denied this information, saying that the boats and engines were bought with money which they had collected themselves. Emigrants procured navigation equipment and life jackets and hired fishermen who steered the boat in exchange for a free trip (Liberti, 2013, p. 16). This way of functioning of illegal trips seems to be justified, because on Senegalese websites, according to the journalist, we can find numerous tips and suggestions on how to cross to Europe. The page www.senegalaisement.com, mentioned by Liberti, reportedly proposes different types of "Europe vacation packages" with the price list and things to consider (Liberti, 2013, p. 17).

The journalist recalls information found on this website that the cost of renting a boat is 4,500 euros, while gasoline, food and security measures are around 60 euros per person. It shows that one emigrant would have to spend 150 euros for a "Europe vacation package". In addition, the Senegal site is said to have posted a message in which we can read that:

Ważne. W żadnym wypadku nie zabierajcie ze sobą żadnych dokumentów. Nie możecie dać się rozpoznać, od tego będzie zależeć powodzenie wyprawy!!! Chodzi o to, że faszystowska policja w Europie nie może wiedzieć, skąd jesteście; wtedy nie mają podstaw by Was odesłać z powrotem [...]. Jeśli uda wam się nie wyjawić waszej tożsamości przez pewien czas, szanse powodzenia sięgają 100\%. (Liberti, 2013, p. 18)

Important: Never take any documents with you. You must not be recognized, the success of the journey depends on it!!! The point is that the fascist police in Europe cannot know where you come from; then they do not have a reason to

\footnotetext{
1 All translations from Italian into English are mine.

2 In order to get acquainted with the activities of FIERI, see the website: http://fieri.it/ (Accessed December 12, 2014).

3 In this article I use the Polish translation of the book, which was published by the publishing house Czarne and its premiere was on 23th October 2013. The book is entitled Na poludnie od Lampedusy. Podróże rozpaczy and it was translated by Marcin Wyrembelski.

4 An example article about illegal criminal organizations also appeared on 23. 04. 2015 in the Polish newspaper "Newsweek". The content of the article is available on the website:

http://swiat.newsweek.pl/przemyt-imigrantow-bardzo-oplacalny,artykuly,361648,1.html (Accessed April 25, 2015).
} 
send you back...If you manage not to reveal your identity for some time, the chance of success is $100 \%{ }^{5}$.

However, when visiting the Senegalese portal www.senegalaisement.com, you are redirected to another portal about Senegal: http://www.planete-senegal.com $/{ }^{6}$, where there is no information mentioned by the Italian journalist in his reportage. Is it a coincidence, a change in the tactics of the page administrators, or perhaps a journalistic mistake? There is no way to guess.

Pierre-Louis, another person interviewed by the Italian reporter, lives in Mbour and makes boats. He did not have a specific opinion about emigration from Senegal, but he was evidently happy with receiving more orders. After a short conversation with Liberti, he said: "You should tell all politicians. They can do whatever they want, but they can never stop this swollen stream of people" (Liberti, 2013, p. 24). These words are confirmed by the first chapter of the reportage, devoted to Mbour.

According to the journalist, the crisis in the fishing village is visible "with the naked eye" (Liberti, 2013, p. 22), and Liberti's interviewees immediately point to the main culprit - the European Union. In their opinion, it is the policy of the Schengen area which has led the city to the crisis: on the one hand, it condemned illegal emigration, and on the other hand, it deprived Senegal of natural resources, thus contributing to the bankruptcy of traditional African hunters ${ }^{7}$. For the inhabitants of the town, the phenomenon of transforming fishing boats into boats carrying migrants, and fishermen into carriers, was quite obvious. People were forced to leave the country by the implemented policy. The residents comment on the masses of immigrants crossing by sea as follows:

Europa nie może pozostawać obojętna wobec tej tragedii. Przede wszystkim nie może przymykać oczu, gdy europejskie łodzie kradną nam ryby, a potem narzekać, że nasi chłopcy płyną szukać szczęścia na Wyspach Kanaryjskich. (Liberti, 2013, p. 22)

Europe cannot remain indifferent to this tragedy. First of all, it cannot turn a blind eye when European boats steal our fish, and then complain that our boys go to seek their fortune in the Canary Islands.

Information gathered by the journalist, the analysis of press reports, statistics and literature describing the topic related to the contemporary condition of the Dark Continent may consistently make a coherent entirety, which is reflected in the opinion of one of illegal migrants:

To co teraz widzicie [...] to efekt waszej polityki: gdybyście przestali robić nieuczciwą konkurencję afrykańskim produktom, gdybyście przestali ograbiać nasze kraje z naturalnych bogactw, gdybyście dotrzymali ustaleń przyjętych w momencie dekolonizacji [...] być może wcale nie musielibyśmy stąd wyjeżdżać. (Liberti, 2013, p. 120)

What you can see now...is the result of your policy: if you stopped the unfair competition for African products, if you stopped robbing our countries of natural resources, if you kept the arrangements made at the time of decolonization...perhaps we would never have to leave from here.

The emigrant's opinion seems to be confirmed by the words of the Italian reporter:

Przeprawy na Wyspy Kanaryjskie [do Europy] były odwetem, zemstą ograbionej Afryki, której synowie osiedlali się teraz thumnie na ziemiach swoich grabieżców, jakby chcieli wymusić w ten sposób rekompensatę za doznane krzywdy. (Liberti, 2013, p. 120)

\footnotetext{
5 All translations from Polish into English are mine.

${ }^{6} \mathrm{http}: / / w w w . p l a n e t e-s e n e g a l . c o m /$ (Accessed April 25, 2015).

7 http://afryka.org/afryka/--8222-przestancie-krasc-nasze-ryby--8221-,news/ (Accessed April 2 5, 2015). In order to get acquainted with the problems afflicting Africa, visit the portal dedicated to Africa: http://afryka.org/.
} 
Crossing to the Canary Islands [to Europe] was a retaliation, a revenge of plundered Africa, whose sons now settled in crowds on the lands of their plunderers as if they had wanted to enforce a compensation for their injustices this way.

However, despite the cited words, Liberti's opinion seems to be a simplified explanation of the phenomenon of immigration from Africa to the European continent. Undoubtedly, Europe suffers from the consequences of the colonial policy applied against Africa for years, but this is not the only motivation that encourages young Africans to emigrate. It was also mentioned by Ryszard Kapuściński, a Polish reportage master and undisputed expert on the subject. In an interview for "Gazeta Wyborcza", he says:

Reporterskie relacje z Afryki są wyrwane z kontekstu i przez to zupełnie niezrozumiałe. Trzeci Świat pokazuje się nam od strony horroru, potworności, a więc z takiej strony, którą można efektownie sfotografować. Nikt nie stara się zrozumieć a potem wyjaśnić, dlaczego raptem milion ludzi rusza w desperacką wędrówkę. Dokonuje się niedopuszczalnych uogólnień, które umacniają tylko stereotyp Afryki jako kontynentu barbarzyńców[...]. (Kostyrko \& Jagielski, 2001)

Reporters' relations from Africa are out of context and thus completely incomprehensible. We are shown the Third World as the horror of atrocities: this is something that looks impressive in photos. No one tries to understand and then explain why suddenly a million of people go on a desperate journey. Unacceptable generalizations are made that only reinforce the stereotype of Africa as a continent of barbarians [...].

The thesis of the Italian journalist resounded in this text so clearly that it suggested a unilateral assessment of the situation. But I do not want to judge, I only want to point out that the perception of the problems of modern Africa - mainly the topic of emigration of Africans - cannot be interpreted only from one though significant, perspective: the post-colonial perspective. The scale of this phenomenon is so huge that it requires the analysis in relation to other factors as well. For the literature created in this exile to be valuable and give explanations, a diligent observation of this environment is necessary. We should look for the causes of intensification of migration towards Europe. This helps to make a diagnosis on the condition of both the African continent and Europe and will enable appropriate measures to help solve the crisis of migration the Old Continent faces. Non-fiction literature created as part of this phenomenon should, therefore, look for the answers concerning the cause of this phenomenon, not duplicate theses known from the public. Multiplication of the same information will not contribute to deeper knowledge of this topic, it will only strengthen the existing opinions, often created on the basis of political correctness, deeply rooted in the European discourse. It should be noted, however, that the observations made by Liberti (who was the first Italian author to present the subject of immigration to Italy as a European problem) introduces the reader to other dilemmas afflicting the Third World.

Liberti's observation of migrants in Africa illustrates the specific grid present in those unique communities. Therefore, it should not be surprising that the journalist wrote:

Migranci pojawiają się przecież w konkretnych miejscach, zbierają się w ściśle określonych punktach. Na szlakach wykształciła się swego rodzaju topografia tranzytowa, w związku z czym każdy podróżnik doskonale wie, gdzie znajdują się miejsca postoju na trasie oraz w jakich miasteczkach warto się zatrzymać, wie także, gdzie przebywają jego rodacy. (Liberti, 2013, pp. 73-74)

Migrants appear in specific places, they gather at specific points. A kind of transit topography has developed on the trails, and therefore, every traveler knows where the places to stop on the route are and what towns are worth stopping, they also know where their compatriots can be met.

Liberti's opinion is also confirmed by the actions organized on the routes of illegal crossings. In Sub-Saharan Africa, there are associations which thanks to European funds organize public campaigns against 
immigration. The activities of these organizations are primarily supported by emigrants who had managed to return to their homeland. In the nomenclature of illegal migrations, they are called passeurs. The functioning of these associations was explained to the Italian journalist by a well-known Nigerian activist, Ilguilas Weila, fighting against slavery and serving as the president of an organization "Timidria" in Nigeria, which deals with the same phenomenon ${ }^{8}$. The man talked about a program funded from the budget of the European Commission: The truth about illegal immigration to Europe (Liberti, 2013, p. 51).

The Nigerian activist, as he claimed, had put road signs in transit locations, which showed information about the dangers of illegal expeditions. The signboards had inscriptions aimed at discouraging migrants from traveling to Europe. Among the inscriptions there were slogans related to AIDS, sexual abuse, slavery, trafficking, and death (Liberti, 2013, p. 52). It is worth noting that each plate also included the logo of the European Union. The organizer of the action claimed that thanks to them, he "reduced the harm" (Liberti, 2013, p. 52) associated with illegal migration and a mass outflow of people from Nigeria.

However, it is undeniable that financial/developmental support offered by the European Union to countries in North Africa is an important factor affecting their policies. The phenomenon of mass repatriation from Libya should not be surprising, then. Liberti wrote that the Libyan leader Gaddafi, trying to "ingratiate" himself to European leaders, sent back many immigrants, and the repatriation even affected people who were sent from Libya after more than twenty years of residence (Liberti, 2013, p. 84). The Libyan dictator decided to make such a move because, according to Tahirou Oumarou - an employee of the Nigerian Ministry of Foreign Affairs:

Kaddafi jest przebiegły. Wykorzystuje presję Europy do usprawiedliwiania swoich działań na forum afrykańskiej opinii publicznej. Mówi: <<Europejczycy mnie o to proszą. To są rasiści. Więc żeby ich zadowolić, niektórych odesłałem do kraju, ale tylko niektórych>>. (Liberti 2013, p. 85)

Gaddafi is cunning. He uses the pressure of Europe to justify his actions to the African public. He says: "Europeans are asking me to do this. They are racists. So to keep them happy, some of them [migrants] I sent back to their countries, but only some of them".

Restrictions on illegal immigration have also been introduced by the European Agency for the Management of Operational Cooperation at the External Borders of the Member States of the European Union-Frontex, which in 2006 announced that its main aims were to strengthen border control of the European Union and to assist communities in organizing repatriation flights for illegal immigrants. In addition, it was to create a network of cooperation within the border guards and "to examine the risk of management of migratory flows" (Liberti, 2013, p. 149). It also established two joint operations. The first of them, Hera, involved the waters of the Atlantic Ocean, whereas Nautilus patrolled the Strait of Sicily. Both were designed to reduce the number of boats of illegal immigrants arriving to Europe (Liberti, 2013, pp. 149-150).

It is also worth mentioning the Mare Nostrum Operation, organized by the Italian government alone. Lasting a year (in late 2013 and 2014), very burdensome for the Italian budget, this air and water operation of the Italian Navy contributed to saving thousands of immigrants. It was carried out in the waters of the Mediterranean Sea near the coast of Lampedusa and mainly involved rescue operations to protect the lives of illegal emigrants who were sailing toward the Italian coasts. The second operation, Triton, led by Frontex and controlled by Italy, was founded upon the completion of the previous operation and is designed to protect the European borders. However,

\footnotetext{
${ }^{8} \mathrm{http} / / /$ www.antislavery.org/search_results.aspx?SearchTerm=timidria (Accessed September 1, 2015).
} 
attention should be paid to the first of the above. In the Mare Nostrum operation, for the first time in the history of the Italian Navy, the commander of one of the ships, Libra, was a woman-Catia Pellegrino.

[...] Catia è la prima donna al comando di una nave militare. Non una nave qualsiasi ma il pattugliatore Libra che, sotto la guida del comandante Pellegrino, 1'11 ottobre 2013 ha salvato 212 migranti naufragati 80 chilometri a sud di Lampedusa. (Pellegrino, 2015, p. 5)

...Catia is the first female commander of a military ship. Not just any ship, but the patrol Libra, the one which under the leadership of commander Pellegrino, on October 11th, 2013, saved 212 drowning migrants 80 kilometers south of Lampedusa.

During 14 months of her duty, Pellegrino saved approximately 300 emigrants from danger. After the mission, the commander published in the publishing house Mondadori a book La scelta di Catia (Catia's Choice) (2015). The monograph, which is also Pellegrino's diary, describes 35 days of work on Libra selected by the author. The publication has the form of a $\log$ in which the author describes situations connected with migrants. A lot of the information provided by Pellegrino has an emotional overtone, because, as she said at a meeting promoting the book ${ }^{9}$, Libra became her home, and situations in which she found herself were connected with human lives.

Telling about the tasks which she had to face, Pellegrino clearly underlines the very fast pace of action. According to the commander, during the rescue there was no time to think and analyze, it was necessary to act efficiently to save as many people as possible. The frantic pace of work can be easily read from the diaries. Short, concise sentences, often ended with an exclamation like military commands, illustrate the tension during the activities. Practicality is a feature of every military person, and therefore it should not be surprising that each entry in the book has this mannerism. It can be illustrated by the following quotation:

[...] Manca ancora l'identificazione dei migranti che avevamo a bordo. Preparo la mia tecnologia all'avanguardia, un foglio di carta e una penna. A ogni migrante è assegnato un numero, con il numero davanti al petto viene fotografato. Sul foglio di carta a quel numero viene associato un nome, una presunta nazionalità, e un'età $[\ldots]$ è una preidentificazione. (Pellegrino 2015, pp. 65-66)

...The migrants we had on board were still not identified. I prepare my avant-garde technology: a piece of paper and a pen. A number is assigned to each migrant and then he or she is photographed with the number in the front of the chest. On a piece of paper, a name, alleged nationality and age are assigned to the number... This is pre-identification.

The memoirs by Pellegrino undoubtedly enrich the analysis of the topic. What is more, they describe these phenomena from the point of view of the person who was assisting the immigrants.

The task entrusted to Pellegrino, the 36-year-old, attractive woman from Apulia in Italy, gained a lot of publicity. All the newspapers wrote about the first woman to be a commander saving human lives. RAI (Radiotelevisione Italiana) and the Italian daily "Corriere della Sera" even devoted a separate documentary and a website with the same name to the commander: La scelta di Catia. 80 Miglia a sud di Lampedusa ("Catia's choice. 80 miles south from Lampedusa") ${ }^{10}$. Apart from the documentary about Catia Pellegrino, you can learn about the subject of illegal crossings and the Mare Nostrum mission, as well as the case of the Italian island Lampedusa.

\footnotetext{
9 The meeting with Catia Pellegrino conducted by journalist Mauro Parissoni took place on 15.05.2015 during XXVIII Salone Internazionale del Libro in Turin as part of the subject block Le Grandi Sale.

${ }^{10} \mathrm{http}: / /$ video.corriere.it/news/la-scelta-di-catia (Accessed May 20, 2015).
} 
However, despite many international actions aimed at protecting the lives of migrants, the problem of immigration still exists. As a result, as long as there are economic reasons for migration, the problem of emigration of Africans will not be resolved properly, as evidenced by the researcher Małgorzata Śpiewak, who believes that the migratory movement from Africa will last as long as Europe needs unskilled labor, maintaining the upward tendency of migration from Sub-Saharan regions, which in the future may lead to problems in socio-economic integration (Śpiewak, 2010).

It is also worth noting, as one of Liberti's interloculators says, that although Europe needs immigrants, it does not want to have to deal with them, making it difficult for migrants to access the countries of the European community by sealing and closing the borders and erecting barriers with the help of the army. This means that only the best, strongest and most intelligent individuals get to the Old Continent, which generates a kind of natural selection (Liberti, 2013, p. 127). Many immigrants encountered by the Italian journalist asked him what Europe was planning to do with regard to the issue of African migration. The emigrants could not understand the resulting paradox: on the one hand, Europe needs "manpower", and on the other, they place weapons on the borders. Liberti called this inconsistency "Europe's schizophrenia"-Europe fights with illegal work but at the same time uses it; in addition, it incurs huge expenditure on defense against the influx of illegal migrants (Liberti, 2013, p. 119).

That discrepancy, according to journalist, motivated many Africans not to give up but to keep trying to get to the desired Europe (Liberti, 2013, p. 119). "Carried by a wave of romantic idealism" (Liberti, 2013, p. 119) as Liberti aptly defines the attitude of immigrants, they no longer referred to their travels as "journeys of hope and despair," but as "expeditions" and they become "travelers", not "convicts" (Liberti, 2013, p. 120). Changing the nomenclature referring to processes occurring in the emigration led to the development of the tendency to take most difficult challenges, and thus, as the Italian journalist writes, "the final value of the success increased with the degree of difficulty of its achievement" (Liberti, 2013, p. 120), in effect attributing initiation properties to the journey to Europe (Liberti, 2013, p. 120). The whole dramatic route of the migrants, in turn, became their own African Odyssey (2009), as a journalist of the German “Der Spiegel”, Klaus Brinkbäumer, aptly titled his book. It should be noted, however, that the report by the German author is written from a different perspective, as the reader learns of the theme of exile at the moment that an illegal emigrant, John Ampan from Ghana, decides to return to his country. Hence, the publication remains a complementation of the issues raised.

Analyzing journalistic reports we might observe that the Old Continent was perceived by illegal immigrants as an antinomy, being at the same time the desired paradise, where all dreams come true, and a colonizing hell (Liberti, 2013, p. 120). There is no doubt, however, that it is exactly how European community member states are presented in reportages by the Italian and German journalists.

\section{Conclusion}

An interesting work on the myths related to the phenomenon of illegal migration is a report by Hein de Hass Irregular Migration from West Africa to the Maghreb and the European Union. An Overview of Recent Trends (2008). The researcher is the deputy director of the International Institute of Migration (IOM) and professor and lecturer at Oxford University and Maastricht, and in his text he presents clear comments on the phenomenon of African emigration. According to the researcher, the problem of the influx of African emigration to the mainland will continue and there is no doubt that the data on more and more people arriving, the expansion of illegal migratory routes and smuggling, and the activities of the European Community, do not 
forecast a quick solution to this burning problem. It is this European schizophrenia, in accordance with Liberti's words, that should be "cured" to be able to think seriously about solving this problem (de Hass, 2008, p. 50). If non-fiction literature is keeps to its main goal-serving people by as sincere and full presentation of facts as possible, if it resists simplification, mythologization and ideologization, which reduces its function of political correctness, it will have the chance to be a bridge in intercultural dialogue. This will let us face the truth of this complicated process, and that is quite a lot...

\section{References}

Armbruster, J. (2012). Arabska wiosna. Rewolucja w świecie islamskim (The Arab spring. A revolution in the Arab World). (R. Kędzierski, Trans.). Wrocław: Wydawnictwo Dolnosląskie.

Balicki, J. (2010). Imigranci z krajów muzułmańskich w Unii Europejskiej: wyzwania dla polityki integracyjnej (Migrants from Islamic countries in the European Union: Challenges for integration policy). Warszawa: Wydawnisctwo Uniwersytetu Kardynała Stefana Wyszyńskiego.

Barrocci, T., \& Liberti, S. (2004). Lo Stivale meticcio - L'immigrazione in Italia oggi (The Boot mestizo-Immigration in Italy today). Roma: Carocci.

Brinkbäumer, K. (2009). Afrykańska Odyseja (The African odyssey). (J. Czudec, Trans.). Wołowiec: Czarne.

de Hass, H. (2008). Irregular migration from West Africa to the Maghreb and the European Union: An overview of recent trends. Geneva: International Organization by Migration. Accessed August $15, \quad 2015$. http://www.heindehaas.com/Publications/de\%20Haas\%202008\%20MRS-32_EN.pdf

Dzięglewski, M. (Ed.). (2012). Migration, identity, ethnicity = Migracje, tożsamość, etniczność. Kraków: Wydawnictwo Naukowe UP.

Furdal, A., \& Wysoczański, W. (Eds.). (2006). Migracje: dzieje, typologia, definicje (Migrations: history, typology, definitions). Wrocław: Wydawnictwo Uniwersytetu Wrocławskiego.

Golemo, K. (2013). Włochy wielokulturowe: regionalizmy, mniejszości, migracje (Multicultural Italy: regionalisms, minorities, migrations). Kraków: Księgarnia Akademicka.

Kawczyńska-Butrym, Z. (2009). Migracje. Wybrane zagadnienia (Migrations. Selected Issues). Lublin: Wydawnictwo Uniwersytetu Marii Curie-Skłodowskiej.

Kostyrko, W., \& Jagielski, W. (2010). Ryszard Kapuściński o sytuacji w Afryce po konflikcie Tutsi i Hutu (Ryszard Kapuściński about the situation in Africa after the Tutsi and Hutu conflict). Accessed October 20, 2010. http://serwisy.gazeta.pl/kapuscinski/1,23084,449562.html

Liberti, S. (2013). Na poludnie od Lampedusy. Podróże rozpaczy (South of Lampedusa. Travels of despair). (M. Wyrembelski, Trans.). Wołowiec: Czarne.

Mickiewicz, P., \& Wyligała, H. (Eds.). (2009). Dokqd zmierza Europa?: nacjonalizm, separatyzm, migracje - nowe wyzwania Unii Europejskie $j$ (Where is Europe heading to?: Nationalism, separatism, migrations — new challenges for the European Union). Wrocław: Wydawnictwo Naukowe Dolnośląskiej Szkoły Wyższej.

Muszyński, W., \& Sikora, E. (Eds.). (2009). Pod wielkim dachem nieba”: granice, migracje i przestrzeń we wspótczesnym społeczeństwie ("Under the great roof of heaven": Boundaries, migrations and the space in the modern society). Torun: Wydawnictwo Adam Marszałek.

Niedźwiedzki, D. (2010). Migracje i tożsamość: od teorii do analizy przypadku (Migration and identity: From the theory to the analysis of the case). Kraków: NOMOS.

Żołądek, Ł. (Ed.). (2014). Migracje i polityka migracyjna (Migrations and migration policy). Warszawa: Biuro Analiz Sjmowych Kancelarii Sejmu: Wydawnictwo Sejmowe Kancelarii Sejmu.

Orłowska, R. (2013). Uwarunkowania i skutki rozwoju migracji ekonomicznych w Unii Europejskiej w świetle wybranych teorii migracji międzynarodowych (Determinants and consequences of evolution of economic migrations in the European Union in the light of selected theories about international migrations). Gdańsk: Wydawnictwo Uniwersytetu Gdańskiego.

Pellegrino, C. (2015). La scelta di Catia (Catia's Choice). Milano: Mondadori.

Sanfilippo, F., \& Scialoja, A. (2010). A Lampedusa. Affari, malaffari, rivolta e sconfitta dell'isola che voleva diventare la porta d'Europa (On Lampedusa. Business, insincerity, revolt and defeat of the island, which wanted to be the gateway to Europe). Roma: Infinto. 
Sgroi, P. (2015). Ospitalità. (Hospitality) Padova: Messaggero.

Śsiewak, M. (2010). Migracje $w$ rejonie Maghrebu (Migrations in the Maghreb area). Accessed May $20,2015$.

http://www.psz.pl/168-archiwum/migracje-w-regionie-maghrebu

\author{
List of websites \\ www.afryka.org \\ www.antislavery.org \\ www.corriere.it \\ www.fieri.it \\ www.gazeta.pl \\ www.heindehaas.com \\ www.planete-senegal.com \\ www.psz.pl \\ www.swiat.newsweek.pl
}

